\title{
Sociaaldemocratie moet zich uit Europese dwangbuis wringen
}

\author{
Ferdi De Ville
}

De Europese sociaaldemocratie kampt met een serieus probleem vandaag. Maar nieuw is dat niet. Ze lijdt al decennia onder een combinatie van problemen die op mekaar inhaken en mekaar versterken. Alleen zijn er recent nog een aantal zaken bijgekomen die ervoor zorgen dat vandaag meer dan ooit de vraag wordt gesteld of de sociaaldemocratie op sterven na dood is.

Die vraag is momenteel echt aan de orde. De diagnose van overlappende crises kan kort als volgt worden gesteld. De Europese sociaaldemocratie heeft het de voorbije jaren gepresteerd één van de ergste kapitalistische crisissen uit de geschiedenis te laten uitdraaien op een ongeziene aanval op de welvaartsstaat. Dat kon gebeuren doordat ze geen coherent links verhaal klaar had (en heeft) over de oorzaken van en een uitweg uit de crisis. Electoraal heeft zich dat vertaald in bijna uitsluitend verkiezingsnederlagen voor sociaaldemocraten de voorbije jaren. In sommige landen zijn ze zelfs zo goed als volledig weggevaagd. Italië en Frankrijk vormen hierop zeldzame uitzonderingen, maar Matteo Renzi en François Hollande hebben hun overwinning eerder te danken aan de massale onvrede over hun voorgangers Nicolas Sarkozy en
Silvio Berlusconi dan aan eigen overtuigingskracht. Als het daarbij bleef, is er eigenlijk zelfs niet zoveel nieuws onder de zon. Ideeëncrisissen en electorale achteruitgang heeft de sociaaldemocratie in het verleden ook gekend. Het is zelfs niet zozeer dat er op haar linkerflank uitdagers zijn opgestaan die successen boeken. Ook vroeger moest de sociaaldemocratie in sommige landen rekening houden met grote concurrenten op de linkerflank. Die nieuwe linkse partijen kunnen zelfs een uitweg tonen. Wat de huidige malaise ernstiger maakt dan alle vorige, is dat de Europese sociaaldemocratie meer dan ooit actief bijdraagt aan haar eigen ontmanteling en dat de meeste sociaaldemocraten zich daar blijkbaar niet van bewust zijn. Dat gebeurt door hoe de sociaaldemocratie zich opstelt in de context van de Europese Unie, ${ }^{1}$ en de eurozone en haar crisis in het bijzonder. De sociaaldemocratie bevindt zich vandaag in Europa in een dwangbuis, maar dan wel een die ze zichzelf heeft aangetrokken en vaak zelf nog wat verder aanspant. Enkel een veel meer assertieve houding binnen de Europese Unie kan de sociaaldemocratie in Europa uit de omklemming helpen.

De huidige Europese crisis rond Griekenland en de rol die verschillende voor- 
aanstaande sociaaldemocraten hierin spelen, illustreren dit treffend. Of wat kan je anders besluiten uit de onverbiddelijke houding van de sociaaldemocraten Jeroen Dijsselbloem (voorzitter van de eurogroep waarin de ministers van Financiën van de eurozone zetelen) en Sigmar Gabriel (vice-kanselier van Duitsland) tegenover de Griekse Syriza-regering? Of nog de verklaring van Renzi dat hij "het vroegtijdige pensioen niet in Italië had afgeschaft zodat de Grieken dat van hun kunnen behouden" (Napoletano, 2015).2 Deze sociaaldemocratische hardvochtigheid leidde tot de uitspraak van de kersverse voorzitter van de Vlaamse sociaaldemocraten (sp.a) John Crombez, dat hij nauwelijks affiniteit voelt met deze Nederlandse, Duitse en Italiaanse collega's (Goossens, 2015). De inkt waarin zijn woorden waren gedrukt was nog niet droog of de sociaaldemocratische voorzitter van het Europees Parlement, Martin Schulz, riep op om de Griekse regering geleid door de 'onbetrouwbare' Alexis Tsipras te vervangen door een technocratenregering (Afhüppe \& Berschens, 2015). Dit alles ontlokte bij de fractieleidster van de Franstalige sociaaldemocraten in de Belgische Kamer van Volksvertegenwoordigers Laurette Onkelinx de analyse: “[d]at er zoiets bestaat als een Europees socialisme is een illusie. De Europese sociaaldemocratische partij weegt niet op tegen de verschillen tussen nationale partijen onderling. In elke stroming zie je die verschillen opduiken, maar bij de socialisten zijn ze toch het grootst" (Imbo \& Eeckhout, 2015). Dit interne debat onder Europese sociaaldemocraten, en het besef dat een sociaaldemocratisch Europa er niet meteen vanzelf zit aan te komen, is een noodzakelijke voorwaarde voor hun wederopstanding.

In het vervolg van dit essay zet ik uiteen tegen welke standaard we de toestand van de sociaaldemocratie in Europa moeten beoordelen; bespreek ik traditionele verklaringen voor de achteruitgang van de sociaaldemocratie; leg ik uit waarom vooral de Europese context een groot probleem voor de sociaaldemocratie vormt; behandel ik de positie van nieuw-linkse partijen in Europa; en formuleer ik conclusies over de toekomst van de Europese sociaaldemocratie in het licht van mijn analyse.

\section{Wat is sociaaldemocratie?}

Voor we een analyse maken van de toestand van de Europese sociaaldemocratie in dit tijdsgewricht, is het nodig de sociaaldemocratie kort te definiëren. We kunnen dit natuurlijk niet overlaten aan de partijen zelf. Zoals we nog zullen uiteenzetten, hebben centrumlinkse partijen zelf de sociaaldemocratie doorheen de geschiedenis geherdefinieerd in reactie op een wijzigende context (en eigenlijk consistent door naar het centrum op te schuiven). Merk ook op dat er partijen zijn, zoals de Portugese Partido Social Democrata (eigenlijk een liberaal-conservatieve partij) die zichzelf sociaaldemocratisch noemen, maar het duidelijk niet zijn. Of sommige van de oudste en grootste sociaaldemocratische partijen in Europa vandaag nog wel aan de definitie van sociaaldemocratie tegemoetkomen, is een vraag die doorheen dit stuk aan bod komt. 
De sociaaldemocratie is historischsociologisch ontstaan als politieke vertegenwoordiger van de arbeidersklasse. Ideologisch lagen haar wortels in de marxistische kritiek op het kapitalisme, maar heeft ze op twee manieren afstand genomen van de klassieke, communistische partijen die ook uit de leer van Marx zijn ontstaan en er dichterbij zijn gebleven. Ten eerste heeft ze heel snel voor reformisme in plaats van revolutie gekozen, wat impliceert dat ze het lot van de arbeidersklasse wil verbeteren langs democratische weg. Ten tweede heeft ze, in navolging van de Duitse SPD na haar conferentie van Bad Godesberg in 1959, het kapitalisme als economisch systeem geaccepteerd, maar wil ze die politiek bedwingen, sturen en corrigeren.

Volgens de Amerikaanse politicologe Sheri Berman (2006) kunnen we de sociaaldemocratische unique selling proposition dan ook het kortst mogelijk definiëren als de verdediging van 'het primaat van de politiek'. In tegenstelling tot andere stromingen die kapitalisme wilden onderwerpen aan publiek bestuur (communisme, nationaalsocialisme of fascisme), kiest ze voor de democratische weg. In tegenstelling tot liberale en conservatieve partijen vindt ze dat de markt ondergeschikt moet zijn aan maatschappelijke keuzes die politiek vertaald worden. Het is vooral dat laatste, waarvan we ons vandaag kunnen afvragen of de sociaaldemocratie deze positie, die dus essentieel is voor haar eigenheid, wel nog echt inneemt.

Het belangrijkste substantiële objectief van de sociaaldemocratie, dat via politieke dominantie over de markt moet worden bereikt, wordt traditioneel onder de noe- mer 'gelijkheid' geplaatst. Na de Tweede Wereldoorlog gaf de sociaaldemocratie het streven naar 'herverdeling van de productiemiddelen' op en werd 'herverdeling van de productieopbrengsten' met een zo hoog mogelijke mate van gelijkheid het doel. Dit moest leiden tot continue lotsverbetering van de arbeidersklasse. De drie decennia na de Tweede Wereldoorlog worden als de gouden periode van de sociaaldemocratie gezien, haar 'trentes glorieuses'. In een context van hoge groei werden overal welvaartsstaten uitgebouwd en verbeterde het lot van een groot deel van de bevolking effectief met rasse schreden. Volgens sommigen waren de ideeën van de sociaaldemocratie toen zo aantrekkelijk (of 'hegemonisch'), dat zelfs conservatieve regeringen een centrumlinks beleid voerden. Anderen menen dat het eigenlijk enkel de uitzonderlijke periode van hoge groei was die toeliet om in sociale vrede zowel hoge winsten voor de bedrijven als vooruitgang voor de arbeiders te genereren (Lavelle, 2008). Mede dankzij de schrik voor het reëel bestaande communistische alternatief in de vorm van de Sovjet-Unie waren het vaak christendemocratische regeringen die de welvaartsstaten uitbouwden; de sociaaldemocratie had daar eerder een beperkte verdienste aan, laat staan dat ze de dominante kracht was, stellen zij. Alleszins, toen de crisis van de jaren zeventig uitbrak, was het uit met de sociaaldemocratische (en keynesiaanse) dominantie, wat ook toen leidde tot een golf aan publicaties over de malaise en toekomst van de sociaaldemocratie (cf. Wolf, 1978). Neoliberalisme werd vervolgens misschien niet overal de dominante ideologie, maar het 
is wel hierdoor dat het wereldwijde beleid sindsdien het best kan worden gekarakteriseerd. Dit zette de sociaaldemocratie ertoe aan om zichzelf in de jaren negentig te herpositioneren. Volgens sommigen was de oplossing echter erger dan de kwaal.

Hieronder zet ik de klassieke verklaringen voor de sociaaldemocratische malaise - waarvan het 'verraad van de derde weg' er één is - uiteen, vooraleer ik inga op het cruciale probleem dat de Europese context vandaag vormt.

\section{Gangbare analyses van de sociaaldemocratische malaise}

Verklaringen voor de malaise van de sociaaldemocratie zijn overvloedig aanwezig. Het kan gerust gesteld worden dat geen enkele andere ideologie, partijfamilie of beleidstraditie meer is geanalyseerd dan de sociaaldemocratie. In sociaalwetenschappelijke termen is de achteruitgang van de sociaaldemocratie 'overgedetermineerd': er bestaan meer aannemelijke verklaringen dan nodig om haar terugval te verklaren. Deze kunnen, van mild naar streng, worden samengevat als 'vier O's': overbodig, oubollig, onuitvoerbaar en overloperig.

Volgens de meest genereuze verklaring is de sociaaldemocratie het slachtoffer van haar eigen succes. Dankzij de lotsverbetering voor de arbeiders na de Tweede Wereldoorlog waartoe zij heeft bijgedragen, is het proletariaat flink geslonken. Een groot deel van de klassieke achterban van de sociaaldemocratie is opgeschoven naar de middenklasse en daarmee meer behoudsgezinde politieke preferenties gaan aanhangen op economisch vlak, terwijl met voldoende brood op de plank en een auto voor en televisie en wasmachine in (bijna) elk huis andere dan sociaaleconomische thema's belangrijker zijn geworden in het maatschappelijke en politieke leven. De sociaaldemocratie is er onvoldoende in geslaagd om zichzelf heruit te vinden en op die manier een nieuwe, stabiele achterban te identificeren voor wie zij met een duidelijk programma de politieke vertegenwoordiger vormt. Ook andere organisaties binnen de zuil, zoals de vakbonden, hebben een dergelijke neergang ondergaan, waardoor de sociaaldemocratie sterke partners in de burgermaatschappij is verloren.

Een daarmee gerelateerde verklaring is dat de sociaaldemocratie oubollig is geworden. Ze is er niet in geslaagd om een progressieve kracht te blijven die op een aantrekkelijke, vernieuwende en offensieve manier een visie op een betere toekomst aandraagt en promoot. Na het wegvallen van klasse als voornaamste breuklijn heeft ze niet via een gemoderniseerd sociaaldemocratisch verhaal een sterke basis in de samenleving langs de nieuwe breuklijnen kunnen vormen. Daardoor heeft ze een deel van haar klassieke achterban zien weglopen naar ethisch-etnisch rechtse of klassiek-linkse partijen, terwijl een progressief deel van de nieuwe middenklasse zich eerder aangetrokken voelt door nieuwe links-ecologische partijen. In de plaats daarvan is de sociaaldemocratie volgens deze diagnose vooral een defensieve, volgens sommigen zelfs conservatieve kracht gebleven die 
enkel weerstand biedt aan de afbraak van haar voornaamste verwezenlijking: de welvaartsstaat. In de ogen van haar grootste critici is het nog erger gesteld: de sociaaldemocratie zou nog louter opkomen voor gevestigde belangen.

Volgens deze twee verklaringen is de malaise van de sociaaldemocratie eerder een probleem voor sociaaldemocratische partijen dan voor sociaaldemocratische idealen. De sociaaldemocratie zou haar doelstellingen grotendeels hebben bereikt, waardoor haar traditionele achterban haar is ontgroeid en ze heeft daar helaas geen antwoord op gevonden. De situatie is in deze zienswijze hopeloos voor sociaaldemocratische politici, maar al bij al niet zo ernstig voor gewone stervelingen. Helaas weten we dat de realiteit minder rooskleurig is. Sinds de jaren zeventig is niet alleen het succes van sociaaldemocratische partijen afgenomen, maar is ook de ongelijkheid opnieuw toegenomen ( $c f$. Piketty, 2014; Atkinson 2015), in sommige landen zelfs spectaculair, en is de markt in het algemeen weer veel dominanter geworden in het organiseren van samenlevingen in steeds meer domeinen. Klassieke industriële arbeiders zijn er inderdaad minder, maar de (vaak tijdelijke en halftijdse) banen in de dienstensector die in de plaats zijn gekomen, zijn vaak niet minder precair, integendeel ( $c f$. Standing, 2011). Als we de klassieke definitie van Marx van het proletariaat nemen - mensen die verplicht worden hun arbeid te verkopen om te kunnen overleven en die zeer weinig autonomie hebben om hun job in te vullen - dan is deze klasse wellicht helemaal niet geslonken. Verder zijn er vormen van discriminatie bijgekomen die eerder los- staan van louter socio-economische factoren. Sociaaldemocratische doelstellingen zijn er dus wel degelijk op achteruitgegaan, waardoor deze eerste twee, genereuze verklaringen niet kunnen volstaan.

Volgens de derde verklaring heeft de sociaaldemocratie dan ook wel degelijk nog steeds duidelijke, onderscheiden objectieven die allesbehalve al vervuld zijn (gelijkheid en politieke beteugeling, sturing en correctie van de markt), maar zijn de recepten om deze doelstellingen mee te bereiken onuitvoerbaar geworden. De voornaamste verantwoordelijke daarvoor is de globalisering, die een sociaaldemocratisch beleid op nationaal niveau onmogelijk maakt ( $c f$. Gray, 1998). Om haar streven naar gelijkheid via herverdeling en publieke diensten als alternatief voor de markt te kunnen financieren, moet de sociaaldemocratie via belastingen voldoende inkomsten kunnen genereren. Door kapitaals- en handelsliberalisering hebben de sterkste schouders zichzelf echter kunnen onttrekken aan proportionele, laat staan progressieve bijdragen, door geloofwaardig te kunnen dreigen met naar het buitenland te vluchten tenzij ze een gunstigere behandeling krijgen (cf. Scharpf, 1991). In het algemeen heeft globalisering ervoor gezorgd dat kapitaal aan structurele macht heeft gewonnen ten opzichte van arbeid en de overheid. De sociaaldemocratie heeft daar eigenlijk altijd zelf toe bijgedragen. Dat mag echter niet simplistisch gezien worden als continu verraad vanwege sociaaldemocratische politici. Hun paradoxale positie (willen herverdelen en de markt reguleren maar tegelijkertijd ondernemers in de watten moeten leggen) is net het gevolg 
van rationeel handelen in een kapitalistische context: zonder groei zijn er geen extra middelen om te herverdelen en te investeren in publieke diensten, en dus is de sociaaldemocratie steeds gedwongen geweest om compromissen te sluiten met investeerders. Het is pas recenter, met de hieronder besproken 'derde weg', dat de sociaaldemocratie niet enkel in de instrumenten maar ook in de doelstellingen zichzelf heeft aangepast aan de (gepercipieerde) realiteit van globalisering.

In reactie op elk van de voorgaande analyses heeft de sociaaldemocratie in de jaren negentig, onder de intellectuele leiding van Anthony Giddens en de politieke leiding van Tony Blair, zichzelf onder de noemer 'de derde weg' geherdefinieerd (Giddens, 1998; Blair, 1998). De uitgangspunten voor deze vernieuwing waren, dat niet alleen de economische context (door globalisering) was gewijzigd met gevolgen voor de haalbaarheid van sociaaldemocratische recepten, maar dat ook de verzuchtingen en wensen van de bevolking waren veranderd en de sociaaldemocratie daarop nieuwe antwoorden moest formuleren. In plaats van mensen te beschermen en te betuttelen van wieg tot graf via een voor herverdeling verantwoordelijke sterke staat, moesten ze handvatten krijgen aangereikt waarmee ze hun eigen geluk kunnen nastreven en daar ook zelf meer verantwoordelijk voor zijn. Van de nood die globalisering voor de sociaaldemocratie betekende, werd op die manier een deugd gemaakt. Dat het niet meer mogelijk is om een klassiek herverdelend beleid te voeren is in deze visie niet erg, want dat is toch niet meer wat moderne burgers verwachten. Zij wil- len niet langer beschermd worden tegen competitieve markten, maar wel gewapend worden om zichzelf op die markten succesvol te kunnen bewegen. Sociaaldemocratie volgens de derde weg nam definitief afstand van de doelstelling om het kapitalisme in te perken, te bedwingen en te corrigeren. Het stelde in de plaats dat het de markt beter tot haar recht kon laten komen dan conservatieven à la Margaret Thatcher. Nog meer dan vroeger zouden sociaaldemocraten eerder managers dan ideologische bestrijders van het kapitalisme worden.

Volgens de vele critici van de derde weg heeft de sociaaldemocratie zichzelf met de derde weg niet heruitgevonden, maar is ze gecapituleerd voor het neoliberalisme (voor één van de vroegste kritieken, zie Hall, 1998). Door een beleid voor te staan en te voeren dat enkel de allerscherpste kantjes van het neoliberalisme wil afvijlen, heeft ze het neoliberalisme louter gelegitimeerd. Dat is volgens vele critici het echte verdriet van de sociaaldemocratie vandaag en de verklaring voor haar onvermogen om van de recente crisis te profiteren. Door zelf de lof van de vrije markt te zwaaien en te stellen dat de rol van de staat niet verder gaat dan burgers te bewapenen om op die markt hun eigen levenskeuzes na te streven en ze op eerder minimalistische wijze te beschermen tegen vooral nieuwe risico's, had de sociaaldemocratie zichzelf helemaal uitgekleed en stond ze in haar blootje toen de financiële crisis toesloeg.

Waar de derdewegadepten en hun critici het over eens zijn, is dat een sociaaldemocratisch beleid op nationaal niveau heel moeilijk, zo niet onmogelijk is gewor- 
den. Het klinkt inderdaad logisch dat het primaat van de politiek over de markt als essentie van de sociaaldemocratie illusoir is geworden als die markt aan nationale politieke controle is ontsnapt. Het antwoord van beide kampen is dat de democratie dan ook maar meer naar het niveau moet getild worden waarop de markt vandaag is georganiseerd (bv. Held, 2003). De meesten kijken daarvoor naar het Europese niveau, omdat in Europa de meeste handel nog steeds intern wordt gevoerd en daar al supranationale instellingen aanwezig zijn. De sociaaldemocratie terug tot leven brengen betekent dus de Europese Unie extra bevoegdheden geven (voornamelijk om meer belastingen te kunnen innen en de opbrengsten daarvan te verdelen, tax-andspend) en haar te democratiseren. Met die aanbeveling eindigen vele analyses van de malaise van de Europese sociaaldemocratie inderdaad (bv. Berman, 2006, p. 214; Rodrik, 2011, pp. 214 e.v.; Giddens, 2013). ${ }^{3}$ Het is ook een argumentatie die sociaaldemocratische politici zelf al lange tijd gebruiken, wanneer zij pleiten voor een 'sociaal Europa'. ${ }^{4}$ Dat moet dienen als een soort kalmeerpil zowel voor Europese politici als voor hun electoraat. Het ontbreken van, maar vooruitzicht op, een sociaal Europa dient handig als respectievelijk een excuus voor het onvermogen om een echt sociaaldemocratisch beleid op nationaal niveau te voeren alsook als een reden tot optimisme5: vandaag zijn we misschien nog in de verdrukking, maar eens we van de Europese Unie ook een sociale en democratische unie hebben gemaakt, dan is het weer aan ons.

Dat geloof in een sociaal Europa dat altijd quasi binnen handbereik is als oplos- sing voor de sociaaldemocratische malaise is even begrijpelijk als naïef. De recente actualiteit heeft uitgewezen dat de Europese constructie eerder een fundamenteel deel van het probleem dan van de oplossing voor de sociaaldemocratie vormt.

\section{Het probleem Europa}

De sociaaldemocratie heeft lang een dubbelzinnige houding ten aanzien van de Europese integratie aangenomen. Hoewel de Europese Unie ook wel sociaaldemocratische vaders kent, zoals de Belg Paul-Henri Spaak, werd de Europese eenheidsmarkt zeker in de eerste decennia wat sceptisch bekeken als toch vooral een conservatief en liberaal project. Maar men focuste zich toen met succes op de uitbouw van de welvaartsstaten op nationaal niveau, waarvoor de Europese Unie in de eerste decennia van beperkte integratie weinig in de weg legde. Dat was het naoorlogse "embedded liberalism” (Ruggie, 1982) compromis: staten kregen de ruimte om sociale zekerheid te bieden op nationaal niveau, terwijl supranationale instellingen (de Europese in de eerste plaats maar op mondiaal niveau bijvoorbeeld ook de Wereldhandelsorganisatie) verzekerden dat staten elkaar niet de duvel zouden aandoen om de eigen economie te bevoordelen. De combinatie van het ontbreken van socialezekerheidsstelsels op nationaal niveau en van internationale instellingen die een beggar-thyneighbour (het stimuleren van de eigen economie via export ten koste van andere landen) beleid konden voorkomen, werd 
als belangrijke economische oorzaak voor het uitbreken van de Tweede Wereldoorlog gezien.

De kentering in de houding van sociaaldemocraten ten aanzien van Europa kwam er (zoals in zovele zaken) in de nasleep van de stagflatiecrisis van eind jaren zeventig-begin jaren tachtig en begon in Frankrijk met de U-turn van François Mitterand. Waar die in het vorige decennium nog stellig had verklaard dat "l'Europe sera socialiste ou ne sera pas" (Escalona \& Vieira, 2014), werd een versterking van Europa zonder veel socialistische condities een onderdeel van zijn ommekeer na het snel mislukte experiment van socialisme in één land. Onder aanvoering van één van zijn voormalige ministers, Jacques Delors, zou de Europese Unie in de volgende tien jaar een dubbele kwalitatieve sprong nemen met het voltooien van de eenheidsmarkt en de invoering van de euro. De hoop was dat in de moeilijke tijden van versnelde globalisering deze sprongen de Europese economie zouden versterken en dat op die manier weer meer ruimte en middelen zouden vrijkomen die een sociaaldemocratisch beleid mogelijk maken en dat negatieve integratie (het wegwerken van allerlei belemmeringen op de interne markt) en monetaire unie uiteindelijk wonderbaarlijk automatisch zouden leiden tot een sociaal Europa.

Helaas hebben sociaaldemocraten hun hoop voor een sociaaldemocratische wederopstanding op het Europese niveau geprojecteerd zonder een duidelijk plan hoe de Europese Unie dan wel sociaal en democratisch moest gemaakt worden. Door dit gebrek aan strategisch inzicht en de gebeurtenissen van eind jaren tach- tig (de val van de Berlijnse Muur en de overhaaste invoering van de euro en uitbreiding van de Unie in reactie erop) is de Europese Unie uiteindelijk een constructie geworden, die de natte droom van neoliberalen als Friedrich Hayek benadert (Harmes, 2012): een structuur waarin het vrij verkeer (van vooral goederen, diensten en kapitaal) constitutioneel is verankerd en op die manier het politieke primaat over de vrijemarktwerking niet alleen juridisch aan banden ligt (het verbod op kapitaalen handelscontroles, maar ook de euroregels over begrotingstekorten en schuld of het verbod op monetaire financiering maken een keynesiaans beleid onmogelijk), maar waarbij er ook georganiseerde concurrentie bestaat op het vlak van belastingen en sociale bescherming tussen de lidstaten, die hierover de formele bevoegdheid behouden. In plaats van dat verdere Europese integratie in een geglobaliseerde wereld ruimte voor sociaaldemocratisch beleid zou heroveren, is net het omgekeerde gebeurd: in de Europese constructie, en in de eurozone in het bijzonder, is de vrijheid voor het voeren van een sociaaldemocratisch beleid kleiner dan het voor gelijk welk ander land elders in de wereld is.

Er bestaan verschillende verklaringen waarom het zo moeilijk is voor de sociaaldemocratie om een 'sociaal Europa' te verwezenlijken. Deels zit links eigenlijk al sinds het prille begin van de Europese integratie in de val. De Europese vrije markt, en later de neoliberale regels die de euro besturen, zijn gebetonneerd in verdragen. Lidstaten kunnen deze dominantie van de vrije markt niet eenzijdig aantasten; ze op Europees niveau terugschroe- 
ven of aanpassen vereist unanimiteit $(c f$. Scharpf, 2006; 2010). Anderzijds, op het supranationale niveau nieuwe regels of beleid invoeren die een sociaal tegengewicht zouden bieden voor de vrije markt en de monetaire unie, is eveneens zeer moeilijk, omdat daarvoor ook de drempel van een supermeerderheid of unanimiteit onder lidstaten (en de minder prohibitieve drempel van een meerderheid in het Europees Parlement) moet overwonnen worden. Dat betekent dat sociaaldemocraten eigenlijk quasi overal in Europa op hetzelfde moment aan de macht moeten zijn om dat lang verlangde sociale Europa te kunnen invoeren. Toen ze dat ook effectief even waren, eind jaren negentig (12 van de 15 toenmalige lidstaten kenden een centrumlinkse regering), hebben ze dat in volle derdewegeuforie nagelaten. In de plaats daarvan werd via de beruchte Lissabon-strategie ${ }^{6}$ het concept van flexicurity het Leitmotiv van de ogenschijnlijke verzoening tussen de vrijemarktwerking en sociale bescherming in Europa.

In die ongunstige structurele context in Europa, met de onmogelijkheid om zowel een sociaaldemocratisch beleid op nationaal niveau te voeren als om daar een antwoord aan te bieden op Europees niveau, slagen sociaaldemocraten er dus ook niet in de handen in elkaar te slaan. Aangezien verkiezingen (zelfs deze voor Europa) in nationale arena's plaatsvinden, zijn linkse politici eerder geneigd om een sociaaldemocratisch mercantilistisch beleid na te streven waarvan ze hopen dat het in eigen land voor de nodige groei zal zorgen, waarmee (meestal teleurstellend) werkgelegenheid wordt gecreëerd en middelen gegenereerd om beperkte herverdeling mee te voeren, dan te coördineren met collega's in andere staten. Het typevoorbeeld hiervan is het beleid onder de SPD van Gerard Schröder in de eerste helft van de jaren 2000. Het is algemeen aanvaard dat Duitsland onder sociaaldemocratisch bestuur toen een beggar-thy-neighbour-andthy-workers-beleid heeft gevoerd, dat de Duitse economie opnieuw met groei liet aanknopen, echter ten koste niet alleen van de competitiviteit van andere landen in (vooral) de eurozone maar ook op de kap van de eigen arbeiders en uitkeringstrekkers (Lapavitsas et al., 2010; Scharpf, 2011). Maar opnieuw: dit kan feitelijk als rationeel gezien worden in de huidige euro-constructie, waar korten op de lonen en loonkosten het enige instrument is dat politici nog in handen hebben om de economie te relanceren. Meer dan de derde weg van New Labour onder Tony Blair hebben de Duitse sociaaldemocraten door dit mercantilistisch beleid echter schade toegebracht aan de sociaaldemocratie in Europa. Het zette niet alleen economisch druk op andere landen om ook de lonen en sociale bescherming neerwaarts aan te passen. Het gaf conservatieve politici ook een voor hun linkse concurrenten vervelend argument over hoe een 'moedig' sociaaldemocratisch beleid in het 'algemeen belang' er zou moeten uitzien, een boodschap die vooral na de crisis zou herhaald worden.

Bovendien zijn er belangrijke en hardnekkige verschillen in sociaaldemocratische visie tussen de verschillende lidstaten in de Europese Unie, die het ontwikkelen van sterke gedeelde standpunten bemoeilijken. Dat geldt zowel voor sociaaldemocratische partijen als bijvoorbeeld voor de 
vakbonden. Ten slotte ontbreekt er ook een Europese 'demos', die van onderuit druk zou kunnen zetten voor het ontwikkelen van een sociaal Europa en zo tegengewicht zou kunnen bieden aan nationale reflexen bij sociaaldemocratische partijen. Hoewel vele sociaaldemocraten en vakbondsleiders zich wel bewust zijn van het coördinatieprobleem waarmee ze zitten en beseffen dat dit enkel via Europese samenwerking kan worden overkomen, bewijst de geschiedenis dat dit niet vanzelf gebeurt.

Terwijl links dus dubbel in de val zit in Europa (de klassieke dwangbuis waarin de sociaaldemocratie sowieso zit in een globale kapitalistische context wordt versterkt door de extra institutionele en structurele disciplinering van de Europese constructie), zit rechts in een zetel. De beperkingen die de Europese Unie oplegt aan de mogelijkheid om de markt politiek te sturen en te corrigeren zijn in lijn met de conservatieve visie op de minimalistische rol van de staat. Conservatieven verwelkomen het verlies aan nationale economische macht die globalisering en Europese integratie veroorzaken met de glimlach. De Europese integratie en (de reactie op) de eurocrisis laten hen toe doelstellingen te realiseren die ze in puur nationale context wellicht niet zouden kunnen bereiken. En opnieuw interageert dit met een dynamiek die ook los van de Europese context speelt. Het verlies aan economische macht van nationale politici zorgt voor een verlies onder burgers aan vertrouwen in de politiek. Dit is iets waar linkse bestuurspolitici meer onder lijden dan rechtse. Niet alleen is hun voorkeur voor een sterke overheid afhankelijk van vertrouwen bij de burgers in publieke instellingen, maar ook wordt hun reputatie meer beschadigd wanneer weer maar eens blijkt dat minder realiseerbaar is dan zij vanuit hun sociaaldemocratische traditie geneigd zijn te beloven. Zo verliezen de linkse regeringspartijen twee keer in Europa. Beleidsmatig aan rechts, waarvan de beleidsvoorkeuren zitten ingebakken in de Europese constructie, en electoraal aan radicale partijen aan beide zijden van het spectrum, die zich helemaal kunnen afzetten tegen het Europese beleid of Europese integratie an sich.

De Europese integratie is om nog een reden extra schadelijk voor sociaaldemocratische politici. Terwijl globalisering hen ook structureel benadeelt, kunnen ze dat nog als een onpersoonlijk proces voorstellen, waarvan zij slachtoffer zijn maar waaraan zij niet medeplichtig zijn (ook al klopt dat niet helemaal). Maar wanneer burgers die van de sociaaldemocratie bescherming en herverdeling verwachten dit onmogelijk gemaakt zien door het Europese niveau, dan zien ze wel degelijk ook sociaaldemocratische gezichten als vertegenwoordigers daarvan. Denken we vandaag bijvoorbeeld maar aan Jeroen Dijsselbloem als gezicht van de hardvochtige eurogroep die mee Griekenland op de knieën heeft gedwongen, Frans Timmermans die verantwoordelijk is voor 'betere regulering' in de EU, maar volgens linkse critici onder die vlag progressieve regelgeving op vlak van milieu- en arbeidsbescherming afbouwt of tegenhoudt, of Martin Schulz die in de periode van het 'Greferendum' voor een technocratenregering in Griekenland pleitte. 


\section{Nieuw links in Europa en het primaat van de politiek}

De koers die de Europese integratie heeft genomen en de recente eurocrisis en de reactie erop in het bijzonder, hebben intussen in sommige landen geleid tot het naar voor komen van nieuwe linkse partijen en het quasi verdwijnen van klassieke sociaaldemocraten. Opnieuw heeft dat verschillende redenen, zeker niet in het minst de corruptieschandalen waarin de oude linkse partijen in Zuid-Europa verwikkeld waren. De nieuwe linkse partijen kenmerken zich echter niet alleen door zich af te zetten tegen het volgens hen rotte 'establishment', maar ook door zich te verzetten tegen de huidige Europese constructie. Democratie, of het primaat van de politiek, staat daarbij centraal. Deze nieuwe linkse partijen onderscheiden zich daarbij niet zozeer door radicale economische standpunten. Eigenlijk zijn hun sociaaleconomische programma's traditioneel sociaaldemocratisch te noemen. Ze onderscheiden zich vooral door de confrontatie met het Europese niveau aan te gaan en de incompatibiliteit van de huidige Europese constructie met het primaat van de politiek en sociaaldemocratisch beleid frontaal aan te kaarten. Ze stellen ondubbelzinnig dat het huidige Europa vernietigend is voor sociaaldemocratische idealen en verliezers oplevert, vooral aan de onderkant van de samenleving. In tegenstelling tot de klassieke sociaaldemocratie nemen ze op die manier een Europees standpunt in dat in overeenstemming is met de onvrede over Europa onder de klassieke achterban van de sociaaldemocratie, de lager opgeleide arbeiders en uitkeringstrekkers, de verliezers van Europese integratie (en globalisering). Die groep verliezers is na de crisis vooral in Zuid-Europa niet alleen veel groter geworden, maar het is voor hen ook alleen maar duidelijker geworden in welke mate het Europese niveau medeverantwoordelijk is voor hun onfortuinlijk lot. Tegelijkertijd, door de nadruk te leggen op het gebrek aan democratie in de huidige Europese constructie, weten deze partijen hoger opgeleide, stedelijke en kosmopolitische kiezers aan te trekken. Vooral Podemos, en in minder mate Syriza, profileert zich doelbewust niet als radicaal-linkse partij, maar als een partij die 'het volk' opnieuw een stem wil geven in de huidige Europese post-democratie (cf. Iglesias, 2015), die vooral een zaak is geworden van een elite van beroepspolitici, eurocraten en lobbyisten ( $c f$. Crouch, 2004).

De receptie van dit nieuwe links, voor het eerst aan de macht in Griekenland, in de rest van Europa is zeer vijandig geweest. Niet enkel omdat Syriza met haar (zoals gezegd vrij gematigde) centrumlinkse economische programma de Europese besparingslogica in reactie op de crisis uitdaagde, maar ook en vooral omdat zij met haar confrontatiestrategie zozeer inging tegen de gangbare praktijk in de EU van consensus en compromis. Doordat zij zich als vertegenwoordiger van het Griekse gewone volk presenteert en daarmee een lijn trekt tussen zichzelf en zowel de traditionele Griekse partijen als de Europese instellingen, werd ze snel als populistisch weggezet. Eenzelfde strategie en dynamiek zien we in Spanje met Podemos. 
Ook de meeste sociaaldemocraten in de rest van Europa hebben zich afgezet tegen Syriza. Hoe kunnen we dat verklaren, gegeven dat Syriza sociaaleconomisch een beleid voorstaat dat nauw aanleunt bij een klassiek sociaaldemocratisch programma? Het speelt natuurlijk mee dat Syriza in Griekenland de sociaaldemocratische partij PASOK heeft gedecimeerd en dat partijen in andere landen vrezen dat hen hetzelfde lot zou kunnen beschoren liggen indien Syriza succesvol blijkt (zogenaamde 'pasokificatie'). Daarnaast gaat de confrontatiestrategie in tegen de compromishouding die de sociaaldemocraten, zoals eerder in dit essay besproken, eerst binnenlands en vervolgens ook Europees alsmaar meer zijn gaan aannemen. Ten slotte zou na electoraal succes het beleidsslagen van Syriza voor vele sociaaldemocraten hun eigen falen aantonen: waar zij lang hebben toegegeven aan het idee dat er geen alternatief is voor het meeleunen met de neoliberale globale en Europese wind, zou Syriza bij succes bewijzen dat er wél een alternatief mogelijk is en dat sociaaldemocraten dus lang te makkelijk hebben ingebonden. Dat is nochtans de harde les die de Europese sociaaldemocratie voor zichzelf wel moet durven trekken.

\section{Lessen voor de toekomst voor de Europese sociaaldemocratie}

De sociaaldemocratie heeft de voorbije decennia verschillende stukken grond onder haar voeten voelen wegschuiven. Een groot deel van de arbeidersklasse heeft zich opgewerkt, maar is daarmee ook uit de sociaaldemocratische vijver gekropen. Nieuwe breuklijnen laten zich niet makkelijk structureren volgens een sociaaldemocratisch verhaal. Globalisering heeft de sociaaldemocratie instrumenten ontnomen om gelijkheid via herverdeling te bewerkstelligen en de markt te beperken, te besturen en te corrigeren. In de ogen van velen was de derde weg een daad van verraad, waardoor sociaaldemocraten ondertussen als medeplichtigen eerder dan slachtoffers van het neoliberalisme gezien worden.

Al deze problemen voor de sociaaldemocratie zijn een combinatie van ongelegen structurele veranderingen met vaak onfortuinlijke reacties door sociaaldemocratische politici zelf (al kunnen die vanuit hun eigen standpunt wel als rationeel gezien worden). In dit essay heb ik beargumenteerd dat de huidige Europese constructie (en de eurozone in het bijzonder) vandaag het grootste probleem voor de sociaaldemocratie vormt. De EU met de euro in haar kern beantwoordt aan de droom van neoliberale denkers: doordat de vrije markt en liberale regels zijn gebetonneerd, afwijkingen op nationaal niveau illegaal zijn en aanpassingen op supranationaal niveau tegen zeer hoge drempels botsen, is sociaaldemocratisch beleid zo goed als onmogelijk geworden. Terwijl ook in de rest van de wereld links beleid beperkt wordt door de context van neoliberale globalisering, is dat nergens anders zo sterk het geval als in Europa. De sociaaldemocratie bevindt zich er in een dubbele dwangbuis. Ze slaagt er niet in om daar door samenwerking vanaf te 
komen. Door nationale reflexen trekt ze die dwangbuis vaak nog strakker aan.

Om al deze redenen heeft de Europese sociaaldemocratie niet kunnen profiteren van de crisis. Integendeel, de aanpak van de crisis in Europa schaadt de sociaaldemocratie, zowel programmatisch als electoraal. De sociaaldemocratie wordt medeverantwoordelijk gehouden voor de crisis en haar resulteren in de afbraak van de welvaartsstaat, onder meer door posities ingenomen voor de crisis, niet in het minst het beggar-thy-neighbour-andthy-workers-beleid van de Duitse SPD. Dit heeft ondertussen nieuwe linkse partijen naar boven en zelfs aan de macht gebracht. Een groot deel van de Europese sociaaldemocratie heeft zich tot nog toe aan de zijde van conservatieve partijen geschaard in de afkeer voor deze nieuwe partijen.

In plaats van als door een wesp gestoken te reageren op de opkomst van nieuwe linkse partijen in (Zuid-)Europa, zou de sociaaldemocratie beter lessen trekken uit hun succes. Sociaaleconomisch nemen deze partijen eerder klassieke centrumlinkse posities in, door te pleiten voor een meer vraaggerichte herstel- en groeistrategie en een eerlijkere spreiding van de lasten van besparingen binnen de samenleving. Het is doordat het sociaaleconomische centrum in Europa zozeer naar rechts is verschoven, dat dit gematigd sociaaldemocratische programma van nieuw-linkse partijen vandaag als extreem aanzien wordt. Ze onderscheiden zich vooral van klassieke sociaaldemocraten door afstand te nemen van de compromisbereidheid die de Europese Unie (en de houding van sociaaldemocraten erin) karakteriseert. Ze articuleren zo de vaststelling die vandaag eigenlijk onontkoombaar is: dat de huidige Europese constructie onverenigbaar is met de sociaaldemocratie en het 'primaat van de politiek' in het bijzonder.

Yannis Varoufakis, de flamboyante en omstreden voormalige Griekse minister van Financiën, verwoordde de houding van hemzelf en zijn partij in februari als volgt: “[w]e've lost everything... So we can speak truth to power" (Smith, 2015). Het is tijd dat de sociaaldemocratie in Europa erkent dat ze indien niet alles, dan toch wel zeer veel is verloren de voorbije decennia door de manier waarop de Europese integratie is verlopen, en dat ze dus rechtuit de gebreken van de huidige Europese constructie mag en moet aanklagen. De strategie van telkens compromissen te zoeken met de conservatieven van de Europese Volkspartij heeft de voorbije jaren en zelfs decennia bitter weinig opgeleverd in de uitbouw van een sociaal Europa. Ook in deze legislatuur, die door Commissievoorzitter Jean-Claude Juncker nochtans de termijn van de laatste kans genoemd werd en die de EU een sociaal gelaat zou bezorgen, kan de sociaaldemocratie voorlopig bitter weinig resultaten voorleggen. In het zogenaamde 'vijf voorzitters- rapport' over de voltooiing van de Economische en Monetaire Unie ontbreken opnieuw ambitieuze voorstellen om de Europese Unie (of de eurozone in haar kern) tot een sociale unie te maken (European Commission, 2015).

De Europese sociaaldemocratie moet hieruit harde maar onvermijdelijke conclusies trekken over haar positie in Europa. Het houdt geen steek de lieve vrede in de Europese Unie te bewaren als die Unie 
een keurslijf is geworden dat de sociaaldemocratie de facto onmogelijk maakt. Op welke progressieve verwezenlijkingen in Europa kunnen de sociaaldemocraten zich recent beroepen (het zou tekenend, lachwekkend en triestig tegelijk zijn moest het antwoord hierop de afbouw van roamingtarieven luiden)? Tijdens de vorige legislatuur (2009-2014) zaten ze dan wel de facto in de oppositie in het Europees Parlement, maar wie weet dat? En is er met de huidige 'Grote Coalitie' tussen de Europese Volkspartij en de Europese Socialisten en Democraten zichtbaar iets veranderd? De slogan van Europese sociaaldemocraten in hun meest recente manifest 'Naar een nieuw Europa' (Party of European Socialists 2014) klinkt hol en dreigt opnieuw te ontgoochelen, indien er geen duidelijke en assertieve strategie achter zit over hoe men die hervorming van Europa in sociale richting dan wel gaat bewerkstelligen. Zal de Europese sociaaldemocratie bij de volgende verkiezingen echt nog een keer affiches met 'naar een sociaal Europa' kunnen en durven hergebruiken? Met de aanpak van de Griekse crisis als climax beginnen alsmaar meer progressieve burgers zich te realiseren dat een sociaaldemocratische hervorming van Europa er niet binnenkort vanzelf aankomt. Dit zomaar blijven beloven zal enkel meer desillusie in Europa én sociaaldemocraten opleveren. Op deze manier zal de Europese sociaaldemocratie kiezers blijven verliezen aan partijen die zich ronduit eurokritisch of eurosceptisch opstellen.

"Willen we het geloof in een eengemaakte en solidaire Europese Unie levendig houden, dan hebben we met zijn allen nu de opdracht om Europa weer socialer te maken. Dat betekent dat we er alles aan moeten doen om die eenmaking - met sociale bescherming voor elke Europeaan - naar boven toe mogelijk te maken", schreef bijvoorbeeld sp.a-voorzitter Crombez opnieuw in een persbericht de dag na het voorlopig akkoord over Griekenland (sp.a, 2015). Als hij het echt meent dat zijn partij er alles aan wil doen, dan moet zijn Europees parlementslid eigenlijk haar vertrouwen in de Grote Coalitie opzeggen (en de sociaaldemocratische collega's in haar groep proberen te overtuigen om dat ook te doen) tot er echte voorstellen voor een sociale unie op tafel komen. De hele Europese sociaaldemocratie moet klaar en duidelijk de gebreken in de EU aanklagen en een aantal hervormingen formuleren die sine qua non zijn voor haar verdere steun aan Europees beleid (ze had dit eigenlijk moeten doen aan het begin van de legislatuur, voordat de nieuwe Europese Commissie van start ging). De sociaaldemocratie heeft die macht: zonder haar is er geen stabiele meerderheid in het Europees Parlement. Ze kan dus in afwachting van echte hervormingen in de richting van een sociaal Europa gewoon alle dossiers blokkeren die de conservatieven eerder nauw aan het hart liggen, zoals het TransAtlantisch Vrijhandels- en Investeringsakkoord. Terwijl ze op die assertieve manier eindelijk echt tracht om werk te maken van een sociaal Europa (in plaats van er enkel lippendienst aan te bewijzen) en op die wijze haar ene (supranationale) arm uit het keurslijf wringt, moet ze op nationaal niveau ruimte heroveren om een sociaaldemocratisch beleid te voeren, ook al gaat dat tegen Europese regels in. In de recente aanpak van Griekenland hebben 
conservatieven getoond dat ze binnen Europa een harde Realpolitik durven voeren. Sociaaldemocraten moeten daar dus ook niet om verlegen zijn.

Enkel op die manier kan de Europese sociaaldemocratie vermijden dat ze in het Europese keurslijf doodgaat door langzame verstikking.

\section{Noten}

1. Ik zal in deze tekst omwille van de leesbaarheid vaak 'Europa' gebruiken waar het eigenlijk correct 'Europese Unie' of 'eurozone' moet zijn.

2. In het in het Engels vertaalde artikel luidt het "[l]isten, we have reformed our pension system, but we didn't take the baby pensions away from the Italians to leave them to the Greeks! (Ed's note: "baby pensions" let public sector workers retire in their $40 \mathrm{~s}$ or 50s)". Later, in aanloop naar de ultieme Eurotop die uiteindelijk een nieuw akkoord voor Griekenland zou opleveren, heeft Renzi zich een stuk soepeler opgesteld door te bepleiten dat de Grieken genoeg toegevingen hadden gedaan en niet nog verder moesten vernederd worden.

3. Voor een overzicht zie Bailey, 2014, pp. 232 e.v.).

4. Al in 1973 publiceerde de toenmalige Europese koepelorganisatie van socialistische partijen een manifest getiteld Towards a Social Europe (Bailey, 2014, p. 232). Als zeer recent voorbeeld kan het nieuwste boekje van de huidige voorzitter van de Waalse socialisten gelden (Magnette, 2015).
5. Bailey (2014) noemt dit "blame displacement" en "faith retention".

6. De doelstelling om van de Europese Unie de meest dynamische knowledge-based economy ter wereld te maken, kwam letterlijk uit het derdewegmanifest van Tony Blair van 1998.

\section{Bibliografie}

Afhüppe, S. \& Berschens, R. (2015). Martin Schulz: "Alexis Tsipras is manipulating people”. Handelsblatt: Global Edition, 3 juli.

Atkinson, A.B. (2015). Inequality: What Can Be Done? Harvard: Harvard University Press.

Bailey, D. (2014). Palliating Terminal Social Democratic Decline at the EU Level. In J.D. Bailey, J.-M. De Waele, F. Escalona \& M. Vieira (Eds.), European Social Democracy during the Global Economic Crisis: Renovation or Resignation? Manchester: Manchester University Press.

Berman, S. (2006). The Primacy of Politics: Social Democracy and the Making of Europe's Twentieth Century. Cambridge: Cambridge University Press.

Blair, T. (1998). The Third Way: New Politics for a New Century. London: Fabian Society.

Crouch, C. (2004). Post-Democracy. Cambridge: Polity.

Escalona, F. \& Vieira, M. (2014). "It Does Not Happen Here Either": Why Social Democrats Fail in the Context of the Great Economic Crisis. In J.D. Bailey, J.-M. De Waele, F. Escalona \& M. Vieira (Eds.), European Social Democracy during the Global Economic Crisis: Renovation or Resignation? Manchester: Manchester University Press. 
European Commission (2015). Completing Europe's Economic and Monetary Union: Report by Jean-Claude Juncker in Close Cooperation with Donald Tusk, Jeroen Dijsselbloem, Mario Draghi and Martin Schulz. Brussels: European Commission.

Giddens, A. (1998). The Third Way. Cambridge: Polity.

Giddens, A. (2013). Turbulent and Mighty Continent: What Future for Europe? Cambridge: Polity.

Goossens, R. (2015). Dijsselboem, Renzi, Gabriel? Heb ik een groot probleem mee. De Standaard, 2 juli.

Gray, J. (1998). False Dawn. New York: The New Press.

Hall, S. (1998). The Great Moving Nowhere Show. Marxism Today, 1(1), 9-14.

Harmes, A. (2012). The Rise of Neoliberal Nationalism. Review of International Political Economy, 19(1), 59-86.

Held, D. (2003). Global Social Democracy. In A. Giddens (Ed.), The Progressive Manifesto: New Ideas for the for the CentreLeft. Cambridge: Polity.

Iglesias, P. (2015). Spain on Edge. New Left Review, 93(May-June), 23-42.

Imbo, L. \& Eeckhout, B. (2015). Laurette Onkelinx: "Een Syriza in België? Wij zijn hier toch al?". De Morgen, 3 juli.

Lapavitsas, C., Kaltenbrunner, A., Lindo, D., Michell, J., Painceira, J.P., Pires, E., Powell, J., Stenfors, A. \& Teles, N. (2010). Eurozone Crisis: Beggar Thyself and Thy Neighbour. Journal of Balkan and Near Eastern Studies, 12(4), 321-373.

Lavelle, A. (2008). The Death of Social Democracy: Political Consequences in the 21st Century. Aldershot: Hampshire.

Magnette, P. (2015). La Gauche ne Meurt Jamais. Luik: Luc Pire Editions.
Napoletano, R. (2015). Italian Prime Minister Matteo Renzi: Here's Why We Are Not in the Line of Fire. Italy24.com, 1 juli.

Party of European Socialists (2014). Towards a New Europe: The Manifesto of the Party of European Socialists. Rome: PES.

Piketty, T. (2014). Capital in the 21st Century. Harvard: Harvard University Press.

Rodrik, D. (2011). The Globalization Paradox: Democracy and the Future of the World Economy. Oxford: Oxford University Press.

Ruggie, J.G. (1982). International Regimes, Transactions, and Change: Embedded Liberalism in the Postwar Economic Order. International Organization, 36(2), 379-415.

Scharpf, F.W. (1991). Crisis and Choice in European Social Democracy. Ithaca, N.Y: Cornell University Press.

Scharpf, F.W. (2006). The Joint-decision Trap Revisited. Journal of Common Market Studies, 44(4), 845-864.

Scharpf, F.W. (2010). The Asymmetry of European Integration, Or Why the EU Cannot Be a "Social Market Economy”. SocioEconomic Review, 8(2), 211-250.

Scharpf, F.W. (2011). Monetary Union, Fiscal Crisis and the Preemption of Democracy. MPIfG Discussion Paper 11/11.

Smith, H. (2015). Greek Finance Minister Yanis Varoufakis: “If I Weren’t Scared, I'd Be Awfully Dangerous”. TheGuardian. com, 13 februari.

Sp.a (2015), Technocratie moet eruit, de democratie er weer in. Persbericht, 13 juli.

Standing, G. (2011). The Precariat. London: Bloomsbury Academic.

Wolf, A. (1978). Review: Has Social Democracy a Future? Comparative Politics, 11(1), 100-125. 